\title{
PERIPHERAL NEUROPATHY IN PATIENTS WITH HEPATITIS VIRUS C INFECTION IN THE AMAZON REGION
}

\author{
Irenio Gomes 1,2,3, Daniel Bocchese Nora ${ }^{2,3,4}$, \\ Nelson Cezar Marquezini', Gerard Said ${ }^{6}$, Ailton Melo $^{3}$
}

\begin{abstract}
Introduction: Hepatitis virus C (HCV) infection is considered a health problem in the State of Acre localized in the Brazilian Amazon which has a prevalence rate of $5.9 \%$. Peripheral neuropathy is a common extra-hepatic manifestation in patients with HCV. Objective: To determine the prevalence of peripheral neuropathies using clinical and neurophysiological parameters. Method: A cross sectional study was perf o rmed in patients assisted by a specialized center of infectious diseases in the State of Acre. All patients completed a clinicoepidemiological questionnaire, physical examination and nerve conduction studies (NCS). Results: We studied 78 patients with mean age 45.5 years (range from 10 to 76 years), two thirds were male, $51 \%$ had at least 8 years of formal education and $96 \%$ lived in the capital city of Acre State. Roughly $34 \%$ of patients complained about paresthesias mainly in upper limbs. The NCS diagnosed multiple mononeuropathy in 11 (14.1\%; IC95\% 7.6-23.2) patients and carpal tunnel syndrome in 4 $(5.1 \%)$ patients. Conclusion: Subclinical involvement of peripheral nerves seems common in patients with $\mathrm{HCV}$, with multiple mononeuropathy the main manifestation of nerve injury in this region as suggested by electrophysiological studies.
\end{abstract}

KEY WORDS: hepatitis virus $\mathrm{C}, \mathrm{HCV}$, peripheral neuropathy, nerve conduction studies, Amazon region, prevalence.

\begin{abstract}
Neuropatia periférica em pacientes com infecção pelo vírus $\mathbf{C}$ da hepatite na região amazônica
RESUMO - Introdução: A infecção pelo vírus da hepatite C (VHC) é considerada um problema de saúde pública no Estado do Acre com uma prevalência de 5,9\%. Neuropatia periférica é uma manifestação extrahepática comum em pacientes com VHC. Objetivo: Determinar a prevalência de neuropatias periféricas através de parâmetros clínicos e neurofisiológicos. Método: Foi realizado estudo transversal em pacientes atendidos em uma clínica especializada de doenças infecciosas do Estado do Acre. Todos os pacientes foram submetidos a um questionário clínico-epidemiológico, exame físico e eletroneuromiografia (ENMG). Resultados: Foram estudados 78 pacientes, com idade média de 45,5 anos (10 a 76), dois terços eram do sexo masculino, $51 \%$ tinha pelo menos 8 anos de educação formal e 95\% moravam na capital do Estado. A p roximadamente $34 \%$ dos pacientes se queixaram de parestesias, principalmente nos membros superiores. A ENMG diagnosticou mononeuropatia múltipla em 11 (14,1\%, IC95\% 7,6-23,2) pacientes e síndrome do túnel do carpo em $4(5,1 \%)$. Conclusão: Comprometimento dos nervos periféricos é comum em pacientes com VHC, sendo neuropatia múltipla a apresentação mais comumente diagnosticada pela ENMG.
\end{abstract}

PALAVRAS-CHAVE: vírus da hepatite C, VHC, neuropatia periférica, eletroneuromiografia, região amazônica, prevalência.

Hepatitis C virus (HCV) infection is cosmopolitan and an important health problem mainly in underdeveloped countries. It is estimated that $1 \%$ of the world population is infected by the $\mathrm{HCV}^{1}$. In the Ama- zon, North region of Brazil, the prevalence of HCV infection is one of the highest in the world, along with some regions in Asia, Africa and East Europe, with a prevalence of $5.9 \%$ in the Acre State (report

\footnotetext{
'Serviço de Neurofisiologia do Hospital Luterano da ULBRA, Porto Alegre RS, Brazil; ${ }^{2}$ Serviço de Neurologia do Hospital São Lucas da PUCRS, Porto Alegre RS, Brazil; 'Divisão de Neurologia e Epidemiologia (DINEP) da Faculdade de Medicina da UFBA, Salvador BA, Brazil; " ${ }^{S}$ eniço de Neurologia do Hospital de Clínicas de Porto Alegre da UFRGS, Porto Alegre RS, Brazil; ${ }^{5}$ Faculdade de Medicina da Universidade Federal do Acre, Brazil; ${ }^{6}$ Service de Neurologie, Centre Hospitalier Universitaire de Bicêtre, Assistance Publique des Hôpitaux de Paris, Université Paris-Sud, France.
}

Received 24 October 2005, received in final form 22 February 2006. Accepted 13 April 2006.

Dr. Irenio Gomes - Rua Pinheiro Machado 282 / 12 - 90035-180 Porto Alegre RS - Brasil. E-mail: ireniogomes@uol.com.br 
of the Study Group of Hepatology Brazilian Society, 2003). The chronic infection determined by the HCV may cause several extra-hepatic problems such as cryoglobulinemia (CG), glomerulonephritis, Sicca syn$\mathrm{d}$ rome or cutaneous porphyria ${ }^{2}$. Peripheral neuropathy (PN) is described in $9 \%$ of patients chronically infected by $\mathrm{HCV}^{3}$ and when cryoglobulinemia is present this number can rise to more than $30 \% 4,5$. Although peripheral neuropathy in HCV has greater association with increased cryoglobulinemia, several papers have described it in the absence of $\mathrm{CG}^{2,6-8}$.

Recently, after finding the virus RNA in nerve biopsies, some authors suggested a direct viral aggression against the nerve ${ }^{9}$. However, PN seems to the result from immunomediated mechanisms determined by the HCV in the nerve rather than related to direct viral infection with consequent in situ lesion in the nervous tissue ${ }^{10}$.

Peripheral neuropathy associated with HCV is usually related to axonal damage, probably secondary to vasculitis, fascicular ischemia and subsequent axonal degeneration ${ }^{11}$. Usually the peripheral nervous system involvement is described as a sensory-motor, distal polyneuropathy often with cryoglobulinemia ${ }^{4,12}$, but isolated mononeuropathy, such as carpal tunnel syndrome or multiple mononeuropathy seem common ${ }^{12,13}$, but studies of large cohorts of patients without cryoglobulinemia are still needed ${ }^{11}$.

In this study we aimed to determine the prevalence and characteristics of peripheral neuropathies, us- ing clinical and neurophysiological parameters, in $\mathrm{HCV}$ patients of the North regions of Brazil.

\section{METHOD}

During the months of May and June 2004, we studied all consecutive patients with HCV attended in a reference center of infectious diseases of the State of Acre, Brazil. The study was approved by the ethic committee of the Federal University, and informed consent was obtained from all subjects. Patients less than 12 years of age or those with any other risk factors to PN or who refused to participate in the study were excluded. Initially, they were submitted to an epidemiological and clinical evaluation and then to nerve conduction studies (NCS) in the lower and upper limbs. The NCS examination was carried out by certified specialists using Medelec-Synergy equipments. In each patient sensory conduction velocity of the median, ulnar, fibular superficialis and sural nerves as well as motor velocities of median, ulnar, common fibular and tibial nerves were recorded. Eletromyographic study or other techniques were performed when needed.

All data were stored in a data base of the program Statistical Package for Social Sciences (SPSS), version 12.0. Descriptive statistic was performed with description of frequencies, confidence intervals, median, media and standard deviation. To compare frequencies among groups, the Pearson chi-square test or Fisher exact test was used. The media we re compared by ANOVA test and data were considered significant if alfa error was inferior to 0.05 .

\section{RESULTS}

We studied 78 patients, age range 10 to 76 years,

Table. Demographic and clinical variables according to neurophysiological diagnosis.

\begin{tabular}{|c|c|c|c|}
\hline \multirow{3}{*}{ Variable } & \multicolumn{2}{|c|}{ Nerve condution study } & \multirow{3}{*}{$\mathrm{p}$} \\
\hline & \multicolumn{2}{|c|}{$\mathrm{N}(\%)$} & \\
\hline & Normal & $\mathrm{MMN}^{1}$ & \\
\hline Male & 39 (61.9) & $11(100.0)$ & 0.013 \\
\hline Age $\left(\right.$ mean $\left.\pm S D^{2}\right)$ & $45.1 \pm 9.90$ & $47.8 \pm 15.2$ & 0.579 \\
\hline More than $8 y$ of formal education & $35(55.6)$ & $2(18.2)$ & 0.017 \\
\hline \multicolumn{4}{|l|}{ Risk factors } \\
\hline $\operatorname{IVDA}^{3}$ & $29(46.0)$ & $5(45.5)$ & 0.972 \\
\hline Previous surgery & $13(20.3)$ & $1(9.1)$ & $0.678^{*}$ \\
\hline Blood transfusion & $11(17.5)$ & $0(0.0)$ & $0.199 *$ \\
\hline Promiscuity & $4(6.3)$ & $1(9.1)$ & $0.564 *$ \\
\hline Time of diagnosis (mean $\pm \mathrm{SD}^{2}$ ) & $4.9 \pm 4.2$ & $6.1 \pm 7.0$ & 0.525 \\
\hline Interferon use & $18(28.6)$ & $2(18.2)$ & $0.716^{*}$ \\
\hline Paresthesias & $20(31.7)$ & $6(54.5)$ & $0.178^{*}$ \\
\hline
\end{tabular}

'MMN, multiple mononeuropathy; ${ }^{2} \mathrm{SD}$, standard deviation; ${ }^{3} \mathrm{VDA}$, intra venous drug abuse; *Fischer test. 
median of 45 and mean $45.5 \pm 10.6$ years. Two thirds of patients were male and $96 \%$ lived in Rio Branco, capital city of Acre State. The majority of patients were white $(56.4 \%)$, with 1 afro-brazilian, and the others mixed of indigens, white and afro-brazilians. More than half of patients $(51 \%)$ had more than 8 years of formal education.

The mean time since the diagnosis of HCV was 5.3 years, $62.8 \%$ of patients were not taking any medication and $29.5 \%$ were taking alpha-interferon. As possible risk factors to HCV we identified intra venous drug abuse in $44.9 \%$, previous surgery in $20.5 \%$, blood transfusion in $16.7 \%$ and sexual promiscuity in $6.4 \%$ of cases.

$P$ a resthesiae occurred in $34.6 \%$ of patients, mainly in upper limbs. Tremor was found in one patient; flaccid tetraparesis in another one (1.3\%). The NCS was normal in 63 patients, multiple mononeuro pathy was found in 11 patients (14.1\%; IC95\% 7.6-23.2) and carpal tunnel syndrome in $4(5.1 \%)$. All multiple mononeuropathies occurred in the males and only one of 4 patients with carpal tunnel syndrome was female. Table shows clinical and demographic variables in patients with normal NCS and in those with multiple mononeuro $p$ at $h y$. In addition to the association between neuropathy and male gender, there was a statistically significant association between patients educated for less than eight years and HCV infection.

\section{DISCUSSION}

In this study we observed $14.1 \%$ of multiple mononeuropathy and $5.1 \%$ of carpal tunnel syndrome in patients with HCV, which is higher than those described in international papers. However, we do not have the results of cryoglobulin, which would allow to determine the prevalence of HCV in these subgroups of patients.

The highest prevalence of carpal tunnel syndrome in male patients differs from other papers that point the female gender as one of the risk factors ${ }^{14}$. However, as our population is predominantly male and the carpal tunnel syndrome is a high prevalent disease, we cannot associate both diseases. We thus estimate that the prevalence of peripheral neuropathy associated with HCV in our population is approximately $14.1 \%$ (IC95\% 7.6-23.2).

It is of interest to note that only a fraction of our population was symptomatic and complained of mild paresthesia. This peculiarity is in keeping with the studied sample that did not search spontaneous med- ical aid. As NCS is a sensitive method to diagnosis large fiber neuropathy, we believe that our patients have an initial picture of nerve involvement, and showed only multiple mononeuropathy, which is different of other papers that related polyneuropathy as the main neuropathic picture ${ }^{10,11}$. Probably polyneuropathy is related to a more advanced stage of disease or risk factors not identified in our population. Long term follow up of one cohort will tell as more about the meaning of our findings.

In conclusion, subclinical involvement of peripheral nerves seems common in patients with HCV. However, some aspects as evolution of the neurologic disease, possible risk factors to appearance of neurologic disease and histologic analysis of nerve will allow a better understanding of the pathophysiological process involved in nerve aggression of patients with $\mathrm{HCV}$, which will permit better therapeutic strategies to this group of patients.

\section{REFERENCES}

1. Yoho R, Cruz L, Mazaheri R. Hepatitis C: a review. Plastic Rescontr Surg 2003;112:597-605.

2. Lidove $\mathrm{O}, \mathrm{Cacoub} \mathrm{P}$, Maisonobe $\mathrm{T}$, et al. Hepatitis $\mathrm{C}$ virus infection with peripheral neuropathy is not always associated with cryoglobulinaemia. Ann Rheum Dis 2001;60:290-292.

3. Cacoub P, Renou C, Rosenthal E, et al. Extrahepatic manifestation of hepatitis $C$ virus infection in 321 patients. Medicine (Baltimore) 2000;79:47-56.

4. Migliaresi S, Di Iorio G, Ammendola A, et al. Peripheral nervous system involvement in HCV-related mixed cryoglobulinemia. Reumatismo 2001;53:26-32.

5. Zaltron S, Puoti M, Liberini $P$, et al. High prevalence of peripheral neuropathy in hepatitis $C$ virus infected patien ts with symptomatic and asymptomatic cryoblobulinaemia. Ital J Gastroenterd Hepatol 1998; 30:391-395.

6. Cacoub P, Poynard T, Ghillani P, Charlotte F, Olivi M, Piette JC. Extrahepatic manifestations of chronic hepatitis. Arthritis Rheum 1999; 42:2204-2212.

7. Lidove $\mathrm{O}$, Maisonobe T, Servan J, et al. Peripheral neuropathy and hepatitis $C$ virus infection: more than cryoglobulinemia. Rev Med Interne 2001;22:939-947.

8. Paoletti V, Donnarumma L, De Matteis A, et al. Peripheral neuropathy without cryoglobulinemia in patients with hepatitis $C$ vírus infection. Panminerva Med 2000;42:175-178.

9. De Martino L, Sampaolo S, Tucci C, et al. Viral RNA in nerve tissues of patients with hepatitis $\mathrm{C}$ infection and peripheral neuropathy. Muscle Nerve 2003;27:102-104.

10. Authier FJ, Bassez G, Payan C, et al. Detection of genomic viral RNA in nerve and muscle of patients with HCV neuropathy. Neurology 2003;60:808-812.

11. Nemni R, Sanvito L, Quattrini A, Santuccio G, Camerlingo M, Canal N. Peripheral neuropathy in hepatitis $C$ vírus infection with and without cryoglobulinaemia. J Neurol Neurosurg Psychiatry 2003;74:12671271.

12. Gemignani F, Pavesi G, Fiochi A, Manganelli P, Ferraccioli G, Marbini A.. Peripheral neuropathy in essential mixed cryoglobulinemia. J Neurol Neurosurg Psychiatry 1992;55:116-120.

13. Apartis E, Leger JM, Musset L, et al. Peripheral neuropathy associated with essential mixed cryoglobulinemia: a role for hepatitis $C$ virus infection? J Neurol Neurosurg Psychiatry 1996;60:661-666.

14. Becker J, Nora DB, Gomes I, et al. An evaluation of gender, obesity, age and diabetes mellitus as risk factors for carpal tunnel syndrome. Clin Neurophysiol 2002;113:1429-1434. 